\title{
HUBUNGAN STATUS KEGAWATDARURATAN DENGAN PENILAIAN TERHADAP PELAYANAN IGD DI RSUD IBNU SINA KABUPATEN GRESIK
}

\author{
CORRELATION EMERGENCY STATUS WITH ATTENDANCE OF EMERGENCY ROOM AT RSUD IBNU SINA \\ KABUPATEN GRESIK
}

Hikmah Ridho Hardyanti, Djazuly Chalidyanto

Fakultas Kesehatan Masyarakat, UniversitasAirlangga, Surabaya

E-mail: hikmahridhoh@gmail.com

\begin{abstract}
The number of non-emergency patients is high from normative visit an indication of problems in the Emergency Room. The purpose of this study to analyze the relationship between the patient's assessment of the provider or hospital with emergency status. This study examines the factors that exist in hospitals, among others, policy about patients who come, the physical condition of buildings, facilities, skilled human resources. The study involved 172 patients who ever went to the Emergency Room RSUD Ibnu Sina Kabupaten Gresik in June 2014, data were taken with visit their homes to conduct interviews based on a questionnaire. The independent variable in this study is the emergency of the patient's status while the dependent variable is the policy of the patients who come, the physical condition of buildings, facilities, skilled human resources. Data were analyzed using the relationship test Chi-square $(\alpha=0.05)$. The study states that the factors comprising hospital policy on patients who come, the physical condition of buildings, facilities and skilled human resources and discipline to have a relationship with the emergency of the patient's status. Variable physical condition of buildings, facilities and skilled human resources need to be considered and improved the quality of emergency services.
\end{abstract}

Keywords: facilities, hospital, status of emergency, the physical condition of buildings

\section{PENDAHULUAN}

Gawat darurat merupakan keadaan klinis pasien yang membutuhkan tindakan medis segera guna penyelamatan nyawa dan pencegahan kecacatan selanjutnya. Pelayanan gawat darurat di dalam Rumah Sakit diselenggarakan oleh Instalasi Gawat Darurat (IGD). Dalam pelayanan gawat darurat seseorang yang mengalami tingkat gawat darurat yang tinggi wajib ditolong terlebih dahulu. Maka untuk memilah pasien yang datang ditinjau dari kegawatdaruratannya menggunakan metode triase. Metode traige berasal dari bahasa Perancis yang berarti memilah. Dalam bahasa Indonesia kata traige menjadi triase. Prinsip utama dari triase adalah menolong para penderita yang mengalami cedera atau keadaan yang berat namun memiliki harapan hidup. Banyak sekali versi dari metode triase namun yang paling banyak digunakan adalah
Simple Triase yang terdiri dari 4 kategori yaitu merah, kuning, hijau dan hitam.

Sebagai unit pertama yang memberikan pertolongan bagi pasien gawat darurat menjadikan Instalasi Gawat Darurat sebagai indikator dalam mutu layanan dalam rumah sakit. Setiap IGD di rumah sakit memiliki standar pelayanan yang diatur dalam Keputusan Menteri Kesehatan nomer 856 Tahun 2009 tentang standar pelayanan IGD. Peraturan tersebut menjelaskan bahwa setiap IGD harus melakukan pelayanan gawat darurat selama 24 jam penuh selama 7 hari berturut-turut, memiliki kebijakan dan prosedur penggolongan pasien, dan evaluasi serta pengendalian mutu. IGD diprioritaskan bagi pasien yang memang gawat, tetapi terkadang pasien yang bukan gawat darurat juga menggunakan unit pelayanan ini. 
RSUD Ibnu Sina Kabupaten Gresik merupakan rumah sakit yang memiliki kewajiban memberikan pelayanan yang baik dan bermutu sebagaimana tercantum dalam Undang- undang Republik Indonesia Nomor 44 Tahun 2009 tentang Rumah Sakit pada pasal 29 ayat 1. Pasal 29 ayat 1 abjad c juga menjelaskan kewajiban Rumah Sakit memberikan pelayanan gawat darurat kepada pasien sesuai dengan kemampuan. Pelayanan yang baik dapat dilihat dari jumlah kunjungan pasien pada suatu pelayanan kesehatan. Berdasarkan data kunjungan pasien IGD di RSUD Ibu Sina Kabupaten Gresik tahun 2007-2012 menunjukkan rata-rata kunjungan pertahun pasien tidak gawat sebesar $28,17 \%$. Angka $28,17 \%$ lebih tinggi daripada kunjungan normatif $5 \%$ pertahun pada akreditasi rumah sakit.

Penelitian ini dilakukan dengan tujuan menganalisis hubungan antara penilaian pasien terhadap provider dengan status kegawatan di RSUD Ibnu Sina Kabupaten Gresik. Manfaat dari hasil penelitian ini dapat digunakan sebagai masukan bagi manajemen rumah sakit dalam upaya peningkatan pelayanan gawat darurat Instalasi Gawat Darurat.

\section{PUSTAKA}

\section{Pelaksanaan Triase di Rumah Sakit}

RSUD Ibnu Sina Kabupaten Gresik telah memiliki prosedur tetap mengenai pelaksanaan triase dengan nomor PT-437.76.72-49. Prosedur tetap tersebut menjelaskan bahwa triase adalah pengelompokkan korban berdasarkan atas berat ringannya trauma/penyebab serta ketepatan, kecepatan penanganan, dan pemindahannya. Triase dilakukan oleh dokter atau perawat yang bertugas di Instalasi Gawat Darurat saat itu. Tujuan pada pelaksanaan traige di rumah sakit khususnya RSUD Ibnu Sina Kabupaten Gresik antara lain untuk menyeleksi korban berdasarkan kegawat-daruratan pasien dan sebagai dasar dari pelayanan darurat dan non darurat.

Dalam pelaksanaan, tingkat kegawatan pasien dikategorikan menjadi 4 kelompok warna yaitu merah, kuning, hijau dan hitam. Pasien dipilih dan dipilah untuk menentukan labelisasi sesuai dengan prioritas. Prioritas 1 dengan warna merah diperuntukkan bagi pasien dengan diagnosa sumbatan jalan nafas, luka tusuk dada, shock, pendarahan pembuluh darah, problema kejiwaan yang serius, ekstremitas yang terpotong dengan pendarahan. Prioritas 2 dengan warna kuning diperuntukkan pada pasien dengan diagnosa combustio tingkat II atau III kurang dari $25 \%$, patah tulang besar, trauma thorax dan bola mata, juga laserasi usus.

Pada prioritas 3 dengan warna hijau diperuntukkan bagi pasien dengan diagnosa contusio musculurum dan laserasi otot ringan, combustio tingkat II $<20 \%$. Sedangkan prioritas 4 dengan warna hitam diperuntukkan pasien dengan diagnosa henti jantung yang kritis, trauma kepala yang kritis dan radiasi yang tinggi. Pasien yang memerlukan pertolongan jiwa dasar langsung dibawa ke ruang resusitasi. 


\section{Prosedur Tetap Penerimaan Pasien IGD Sebelum}

\section{Masuk Area Triase}

RSUD Ibnu Sina Kabupaten Gresik sudah memiliki prosedur tetap tentang penerimaan pasien IGD sebelum masuk area triase dengan nomor dokumen PT.437.76.23-103. Prosedur tetap tersebut menyatakan bahwa penerimaan pasien datang adalah serangkaian kegiatan penerimaan sampai dilakukan triase serta melakukan pendaftaran pasien yang datang ke IGD selama 24 jam.

Alur prosedur penerimaan pasien sebelum masuk area triase dimulai dengan perawat atau bidan mengambil alat transportasi sesuai dengan kebutuhan. Kemudian perawat atau bidan menyapa ramah dan berkomunikasi yang baik dengan pasien. Langkah selanjutnya bila ada kegawatan, perawat meminta bantuan perawat lain untuk membantu mengkondisikan pasien. Hal ini dilakukan perawat apabila pasien mengalami gangguan jalan nafas, trauma servikasi, dan tulang belakang. Setelah mengkondisikan pasien, perawat memindahkan pasien dari transportasi (mobil,ambulan) ke alat transportasi (kursi roda, brankard). Setelah dipindahkan maka perawat membawa pasien ke area triase.

\section{Persyaratan Bangunan Instalasi Gawat Darurat} Instalasi Gawat Darurat (IGD) memiliki persyaratan bangunan yang telah diatur dalam Kementerian Kesehatan RI (2012) pada Pedoman Teknis Bangunan Rumah Sakit Ruang Gawat Darurat. Dalam pedoman tersebut menjelaskan bahwa bangunan gedung ruang gawat darurat merupakan konstruksi bangunan yang diletakkan secara tetap dalam suatu lingkungan. Bangunan dapat dibangun di atas tanah/perairan, ataupun di bawah tanah/ perairan, tempat manusia melakukan kegiatan. Bangunan ruang gawat darurat terletak dilantai dasar dengan akses masuk yang mudah dicapai terutama untuk pasien yang datang dengan menggunakan ambulan. Pintu masuk bangunan ruang gawat darurat harus terpisah dengan pintu utama masuk rumah sakit atau dengan pintu masuk untuk pasien rawat jalan/ poliklinik. atau pintu masuk bangunan penunjang rumah sakit.

Lokasi bangunan ruang gawat darurat harus dapat dengan mudah dikenal dari jalan raya baik dengan menggunakan pencahayaan lampu atau tanda arah lainnya. Rumah Sakit yang memiliki tapak berbentuk memanjang mengikuti panjang jalan raya, maka pintu masuk ke area IGD disarankan terletak pada pintu masuk yang pertama kali ditemui oleh pengguna kendaraan untuk masuk ke area rumah sakit

\section{Sumber Daya Manusia di Instalasi Gawat Darurat}

Dalam melakukan pelayanan gawat darurat, dibutuhkan sumber daya manusia yang baik. Sumber daya manusia yang dibutuhkan telah diatur dalam Kepmenkes Nomor 856 tahun 2009 tentang Standar IGD. Standar IGD menjelaskan bahwa sumber daya manusia yang dibutuhkan oleh suatu rumah sakit disesuaikan dengan tipe rumah sakit. RSUD Ibnu Sina Kabupaten Gresik merupakan rumah sakit tipe $B$ pendidikan. Rumah sakit tipe $B$ pendidikan membutuhkan 7 jenis sumber daya manusia yaitu dokter spesialis, PPDS, dokter umum, perawat kepala, perawat, non medis bagian keuangan, keamanan dan ketertiban (kamtib), dan pekarya. 
Dokter spesialis antara lain bedah, obsgyn, anak, penyakit dalam yang harus siap dihubungi oleh IGD selama 24 jam penuh bila memerlukan konsultasi. Dokter PPDS dan umum harus ada 24 jam penuh di IGD. Perawat, non medis bagian keuangan, kamtib dan pekarya harus ada selama 24 jam penuh di IGD. Dalam melakukan pelayanan gawat darurat yang wajib diselenggarakan selama 24 jam penuh dan 7 hari berturut-turut maka diperlukan pembagian 3 shift kerja yaitu pagi, sore dan malam.

\section{Pengertian Keterampilan Karyawan}

Pada dasarnya keterampilan merupakan hal yang bersifat individual. Setiap individu akan memiliki tingkat keterampilan yang berbeda tergantung pada kemampuan dan pengalamannya. Keterampilan kerja memiliki manfaat yang besar bagi individu, perusahan, dan masyarakat. Bagi individu, keterampilan kerja dapat meningkatkan prestasinya sehingga memperoleh balas jasa yang sesuai deangan prestasinya. Menurut Wahyudi (2002) Keterampilan adalah kecakapan atau keahlian untuk melakukan suattu pekerjaan hanya diperoleh dalam praktek.

\section{Jenis Jenis Keterampilan}

Jenis keterampilan ada lima yang disebutkan oleh Silalahi (2002) antara lain: Keterampilan teknik (Technical Skills) merupakan kompetensi spesifik untuk melaksanakan tugas atau kemampuan menggunakan teknik, alat, prosedur dan pengetahuan tentang lapangan yang dispesialisasi secara benar dan tepat dalam pelaksanaan tugasnya. Salah satu contoh dari pekerjaan yang membutuhkan keterampilan teknik adalah karyawan operator mesin, dan radiografer.

2. Keterampilan Administrasi

Keterampilan administrasi merupakan kemampuan sesorang dalam merencanakan, mengatur, mengurus, dan mencatat berbagai informasi. Keterampilan ini mencakup kemampuan untuk mengikuti kebijakan dan prosedur, mengelola anggaran. Contoh karyawan yang membutuhkan keterampilan administrasi lebih besar adalah administrator sebuah perusahaan.

Keterampilan hubungan manusia adalah kemampuan untuk memahami dan memotivasi orang lain, sebagai individu atau dalam kelompok. Kemampuan ini berhubungan dengan kemampuan menyeleksi pegawai, memahami orang lain, memberi motivasi dan bimbingan, dan mempengaruhi para pekerja, baik secara individual atau kelompok. Semua pekerjaan membutuhkan keterampilan hubungan manusia.

Keterampilan konseptual adalah kemampuan mengkoordinasi dan mengintregrasi semua kepentingan dan aktifitas organisasi. Keterampilan ini juga membutuhkan kemampuan dalam mendapatkan, menganalisis dan menginterpretasi suatu informasi yang diterima dari berbagai sumber. Keterampilan konseptual mencakup beberapa kemampuan dalam melihat organisasi sebagai suatu keseluruhan dan memahami hubungan, ketergantungan antar unit. Contoh karyawan yang membutuhkan kemampuan konseptual lebih besar adalah manajer tingkat menengah dan supervisor.

5. Keterampilan diagnosis

Keterampilan diagnosis berhubungan dengan 
kemampuan menentukan sesuatu melalui analisa dan pengujian hakekat dari suatu kondisi khusus. Keterampilan diagnostik dapat dimaknakan sebagai kemampuan secara cepat mendapatkan sebab yang benar dari suatu situasi tertentu melalui data dari observasi dan fakta. Contoh karyawan yang membutuhkan keterampilan diagnosis adalah dokter.

\section{METODE}

Penelitian ini menggunakan pendekatan observasional dengan rancang bangun cross sectional. Sampel dalam penelitian adalah 172 pasien dari total populasi jumlah kunjungan pada tahun 2012 sebesar 20.577. Sampel merupakan pasien yang telah memanfaatkan pelayanan IGD di RSUD Ibnu Sina Kabupaten Gresik. Cara pengambilan sampel dilakukan dengan simple random sampling.

Berdasarkan data kunjungan RSUD Ibnu Sina Kabupaten Gresik, sampel diambil pada data rekam medik bulan Juni 2014 dari tanggal 1 sampai dengan 30. Tanggal 1 sampai 20 Juni diambil secara acak 100 orang, kemudian 21 sampai 28 diambil 56 orang dan 29 sampai 30 diambil 16 orang.

Penelitian dilakukan pada pasien yang sudah pernah berobat ke IGD RSUD Ibnu Sina Kabupaten Gresik. Penelitian dilakukan dengan mendatangi rumah responden untuk mendapatkan data penelitian.
Alat ukur penelitian dengan menggunakan kuesioner. Kuesioner penelitian terdiri dari 37 pernyataan. Pilihan jawaban dari pertanyaan menggunakan 4 kategori yaitu sangat buruk (skor 1), buruk (skor 2), baik (skor 3) dan sangat baik (skor 4). Untuk menganalisis hubungan maka teknik analisis data menggunakan uji hubungan chi square.

\section{HASIL DAN PEMBAHASAN}

Berikut dijabarkan hasil penelitian mulai dari gambaran jumlah pasien ditinjau dari status kegawatan, penilaian responden (pasien) tentang IGD, dan analisis hubungan penilaian pelayanan dengan status triase.

\section{Gambaran Jumlah Pasien Ditinjau dari Status Kegawatan Pasien}

Gambaran jumlah pasien ditinjau dari status kegawatan dijelaskan pada Tabel 1. Berdasarkan Tabel 1 diketahui bahwa sebanyak 46 orang (26,74\%) berstatus tidak gawat daurat dan 126 $(73,26 \%)$ orang berstatus gawat darurat.

Penelitian ini melibatkan pasien untuk menilai pelayanan IGD RSUD Ibnu Sina Kabupaten Gresik. Penilaian meliputi 4 variabel yang dinilai yaitu kebijakan pasien yang datang, kondisi fisik sarana, fasilitas dan sumber daya manusia yang terampil. Hasil penilaian pasien terhadap IGD RSUD Ibnu Sina Kabupaten Gresik ditinjau dari 4 variabel ditunjukkan pada Tabel 2.

Tabel 1 Gambaran Jumlah Pasien Ditinjau dari Status Kegawatan Pasien

\begin{tabular}{lll}
\hline Status Pasien & Jumlah & $\begin{array}{l}\text { Persentase } \\
(\%)\end{array}$ \\
\hline Pasien tidak gawat darurat & 46 & 26,74 \\
\hline Pasien gawat darurat & 126 & 73,26 \\
\hline
\end{tabular}


Tabel 2 Penilaian Responden terhadap IGD RSUD Ibnu Sina Kabupaten Gresik

\begin{tabular}{|c|c|c|c|c|c|c|c|c|c|}
\hline \multirow{3}{*}{ No. } & \multirow{3}{*}{ Variabel } & \multicolumn{8}{|c|}{ Kategori Penilaian } \\
\hline & & \multirow{2}{*}{\multicolumn{2}{|c|}{$\begin{array}{c}\text { Sangat Baik } \\
\text { Jumlah Persentase }\end{array}$}} & \multicolumn{2}{|r|}{ Baik } & \multicolumn{2}{|c|}{ Buruk } & \multicolumn{2}{|c|}{ Sangat Buruk } \\
\hline & & & & Jumlah & Persentase & Jumlah & Persentase & Jumlah & Persentase \\
\hline 1 & $\begin{array}{l}\text { Kebijakan tentang } \\
\text { pasien yang datang }\end{array}$ & 50 & $29,1 \%$ & 21 & $12,2 \%$ & 45 & $26,2 \%$ & 56 & $32,6 \%$ \\
\hline 2 & Kondisi fisik sarana & 62 & $36,0 \%$ & 44 & $25,6 \%$ & 9 & $5,2 \%$ & 57 & $33,1 \%$ \\
\hline 3 & Fasilitas IGD & 53 & $30,8 \%$ & 75 & $43,6 \%$ & 23 & $13,4 \%$ & 21 & $12,2 \%$ \\
\hline 4 & $\begin{array}{l}\text { Sumber daya } \\
\text { manusia yang } \\
\text { terampil }\end{array}$ & 58 & $33,7 \%$ & 35 & $20,3 \%$ & 27 & $15,7 \%$ & 52 & $30,2 \%$ \\
\hline
\end{tabular}

Tabel 2 menunjukkan untuk variabel kebijakan tentang pasien yang datang sebesar $32,6 \%$ responden menilai terkategori sangat buruk. Responden yang menilai sangat buruk mengatakan bahwa ketika pasien datang tidak segera ditangani tetapi hanya ditanyai saja. Pelaksanaan kebijakan tentang pasien yang datang ke IGD dinilai belum berjalan dengan baik dalam pelayanan gawat darurat. Kebijakan merupakan hal yang penting dalam pelayanan gawat darurat.

Adanya kebijakan yang jelas dalam mengatur pasien yang datang ke IGD dan disosialisasikan maka tidak ada perbedaan dalam menangani pasien yang datang sesuai dengan kehendak dari pegawai. Kebijakan juga merupakan dasar acuan tindakan bagi petugas medis atau pegawai di IGD dalam melakukan pelayanan. Pelaksanaan kebijakan tersebut dinilai belum berjalan dengan baik dalam pelayanan gawat darurat. Kebijakan merupakan hal yang penting dalam pelayanan, dengan adanya kebijakan yang jelas dalam mengatur pasien yang datang ke IGD maka tidak ada perbedaan dalam menangani pasien yang datang sesuai dengan kehendak dari pegawai. Kebijakan juga merupakan dasar acuan tindakan bagi petugas medis atau pegawai di IGD dalam melakukan pelayanan.

\section{Penilaian Pelayanan Gawat Darurat}

Variabel kondisi fisik sarana IGD RSUD Kabupaten Gresik dinilai oleh responden sangat baik sebesar $36 \%$. Penilaian pasien pada variabel tersebut ditinjau dari segi kondisi dan tata letak bangunan gawat darurat. Penilaian terhadap kondisi fisik sarana perlu dilakukan karena pada UndangUndang Republik Indonesia No. 44 tahun 2009 tentang Rumah Sakit pasal 10 disebutkan bahwa ruang gawat darurat adalah salah satu ruang yang disyaratkan harus ada pada bangunan rumah sakit. Ruang gawat darurat merupakan ruang pelayanan khusus yang menyediakan pelayanan yang komprehensif dan berkesinambungan selama 24 jam. IGD RSUD Ibnu Sina Kabupaten Gresik sudah sesuai bila ditinjau dari pedoman persyaratan bangunan ruang gawat darurat dan standar IGD.

Penilaian variabel fasilitas Instalasi Gawat Darurat meliputi keamanan, telepon umum, apotik dan peralatan medis juga ambulan yang merupakan pendukung layanan gawat darurat. Dalam Kepmenkes Nomor 856 Tahun 2009 tentang IGD menyatakan bahwa untuk mewujudkan pelayanan gawat darurat yang baik dapat dilakukan dengan meningkatkan sarana, prasarana, sumber daya manusia, dan manajemen IGD sesuai dengan standar. Hasil penilaian pasien terhadap fasilitas IGD 
43,6\% menilai sudah baik. Fasilitas Instalasi Gawat Darurat yang dimiliki oleh RSUD Ibnu Sina Kabupaten Gresik sudah sesuai persyaratan minimal yang ditentukan dengan Kepmenkes Republik Indonesia Nomor 856 tentang standar IGD.

Sumber daya manusia yang dimaksud dalam penelitian ini adalah dokter jaga, perawat, dan petugas administrasi. Ketiga sumber daya manusia tersebut melakukan kontak lakngsung dengan pasien. Sumber daya manusia yang terampil menentukan pelayanan gawat darurat tersebut baik dan buruk. Karena sumber daya manusia yang terampil dan cekatan dibutuhkan dalam IGD. Mengingat IGD merupakan unit pelayanan yang mengedepankan kegawatan kondisi pasien bukan dari waktu urut kedatangan. Kriteria SDM yang termasuk dalam tim kerja mempunyai keahlian khusus diantaranya dokter dan perawat yang mempunyai sertifikat ATLS, memiliki ijin praktek yang sah untuk dokter, dan mengikuti pelatihan minimal 20 jam per tahun. Hasil penilaian pasien pada variabel SDM yang terampil sebesar 33,7\% menjawab sangat baik. SDM yang dimiliki oleh RSUD Ibnu Sina Kabupaten Gresik sudah mempunyai kemampuan dan keterampilan yang baik, diantaranya dokter jaga sudah memiliki sertifikat ATLS, ijin praktek yang sah dan mengikuti pelatihan yang berhubungan dengan gawat darurat.

Analisis Hubungan Penilaian IGD terhadap Status Kegawatan Pasien

Hasil uji statistik Chi-Square untuk menganalisis hubungan antar variabel ditunjukkan pada tabel 3. Keempat variabel yaitu kebijakan pasien yang datang, kondisi fisik sarana, fasilitas, dan keterampilan SDM memiliki hubungan dengan status kegawatan pasien. Semakin baik pelaksanaan kebijakan pasien yang datang, kondisi fisik sarana, fasilitas, dan SDM yang terampil yang dimiliki oleh IGD rumah sakit maka akan semakin banyak pula pasien yang menggunakan pelayanan gawat darurat.

Untuk variabel kebijakan tentang pasien yang datang ke IGD berhubungan dengan status kegawatan pasien dikarenakan pelaksanaan dari kebijakan tersebut masih longgar. Seharusnya pasien berstatus tidak gawat yang datang ke IGD dialihkan ke poli rawat jalan, tetapi dalam pelaksanaan kebijakan pasien yang datang menjadi sebaliknya. Sehingga pasien tidak gawat darurat lebih suka datang ke IGD daripada ke poli rawat jalan.

Variabel kondisi fisik sarana mempunyai hubungan dengan status kegawatan pasien. Hal tersebut dikarenakan kondisi fisik sarana yang dimilliki IGD sudah cukup memenuhi persayaratan

Tabel 3 Hasil Uji Hubungan penilaian terhadap Status Kegawatan Pasien

\begin{tabular}{llll}
\hline No & Variabel & Signifikansi & Keterangan \\
\hline 1. & Kebijakan tentang Pasien yang Datang & 0,003 & Ada Hubungan \\
\hline 2. & Kondisi Fisik Sarana & 0.000 & Ada Hubungan \\
\hline 3. & Fasilitas IGD & 0,000 & Ada Hubungan \\
\hline 4. & Keterampilan Sumber Daya Manusia & 0,040 & Ada Hubungan \\
\hline
\end{tabular}


yang ditetapkan. Selain itu, letak bangunan gawat darurat yang strategis dan mudah dijangkau yaitu di bagian depan rumah sakit menjadi alasan utama pasien datang ke IGD. Dalam bangunan IGD memiliki ruang tunggu yang nyaman dan segala urusan administrasi terletak dalam satu lini. Ini memudahkan keluarga pasien dalam mengurus administrasi. Kemudahan dan kenyamanan yang dirasakan pasien membuat pasien tidak gawat cenderung datang ke IGD.

Variabel fasilitas IGD berhubungan dengan status kegawatan pasien yang disebabkan fasilitas yang lengkap dan dibutuhkan oleh pasien ada dalam satu area. Sehingga pasien tidak perlu berjalan jauh dan berpindah bangunan untuk mendapatkan kebutuhan yang diinginkan. Fasilitas IGD antara lain ruang tunggu IGD nyaman yang dilengkapi telepon umum, toilet, dan penjagaan oleh satpam, adanya apotik yang berdekatan dengan IGD, dan peralatan medis yag lengkap. Kelengkapan fasilitas, kenyamanan, dan kemudahan mendorong pasien terutama yang berstatus tidak gawat untuk datang ke IGD dibandingkan dengan unit lain.

Variabel keterampilan SDM berhubungan dengan status kegawatan pasien. Hal ini terjadi disebabkan karena SDM yang dimiliki oleh IGD lebih unggul daripada unit lain. Pasien yang datang ke IGD disambut dengan ramah oleh SDM IGD. SDM di IGD mampu menangani pasien dengan tenang, sabar, cepat, dan tepat yang menjadikan pasien puas dengan pelayanan. Hal tersebut menjadikan pasien berstatus tidak gawat menjadi puas dan suka dengan SDM di IGD dibandingkan dengan unit lain. Bila suatu hari pasien sakit, maka IGD menjadi tujuan pertama dalam mencari pengobatan. Sehingga jumlah pasien yang datang ke IGD dan berstatus tidak gawat menjadi bertambah.

\section{SIMPULAN}

Penilaian empat variabel terhadap IGD RSUD Ibnu Sina Kabupaten Gresik yang masih buruk adalah variabel kebijakan pasien yang datang, sedangkan ketiga variabel lainnya yaitu kondisi fisik sarana, fasilitas, dan sumber daya yang terampil dinilai sudah baik oleh pasien. Penilaian buruk terhadap variabel kebijakan pasien yang datang disebabkan karena pelaksanaan dari kebijakan tersebut masih belum sesuai dan tidak mensosialisasikan kepada pasien dengan jelas. Sosialisasi bukan berupa seminar atau diskusi tapi peraturan tertulis yang dipampang bahwa kebijakan tentang pasien yang datang di IGD.

Keempat variabel terbukti memiliki hubungan dengan status kegawatan pasien. Variabel penelitian merupakan bagian dari persyaratan minimal dari penyelenggaraan gawat darurat suatu rumah sakit yang telah diatur dalam standar IGD. Kelonggaran kebijakan pasien yang datang ke IGD terutama pasien gawat darurat, kelengkapan fasilitas, kondisi fisik sarana yang tata letaknya memudahkan pasien menggunakan pelayanan, dan keterampilan SDM yang sangat baik menjadi alasan utama bagi pasien untuk menggunakan pelayanan IGD. Pasien tidak gawat pun cenderung menggunakan pelayanan IGD dibandingkan dengan unit lain. Sehingga jumlah pasien berstatus tidak gawat yang datang ke IGD menjadi banyak. 
Saran yang diberikan pada penelitian ini adalah Melakukan perbaikan bangunan khususnya jumlah ruangan untuk triase dan tindakan untuk pelayanan gawat darurat yang lebih baik, mengingat RSUD Ibnu Sina sebagai rumah sakit rujukan di Kabupaten Gresik. Memperbaiki alat kesehatan penunjang pelayanan yang telah rusak, seperti standar infus, manometer, timbangan BB, ambu bagian dewasa

\section{DAFTAR PUSTAKA}

Bambang Wahyudi, Drs. 2002. Manajemen Sumber Daya Manusia. Bandung: Sulita.

Gentile, Stepahanie., V. Pascal, CL. Anne, G. Sabina , 2010. Nonurgent patients in the emergency department? A French formula to prevent misuse. BMC Health Services Research $(10,66)$.

Kemenkes, RI. 2012. Pedoman Teknis Bangunan Rumah Sakit Ruang Gawat Darurat.

Keputusan Menteri Kesehatan Republik Indonesia Nomor 340 Tahun 2010 tentang Klasifikasi Rumah Sakit.

Keputusan Menteri Kesehatan Republik Indonesia Nomor 856 Tahun 2009 tentang Standar IGD.

Norredam., Marien, Krasnik., Allan, Sorensen., Tine Moller, Keiding., Niels, Michaelsen., Jette Joost, Nielsen., Annete Sonne. 2004. Emergency Room Utilization $\mathrm{n}$ Copenhagen: a Comparison of Immigrant Groups and Danish-born residents. Scandinavian Journal of Public Health,(53-59).

Ulber, Silalahi. 2002. Pemahaman Praktis Asas-Asas Organisasi, Bandung: Mandar Maju.

Russ, Stephan., Jones, lan., Aronsky, Dominik., S.Dittus, Robbert., Slovis, Corey M. 2010. Placing Physician Orders at Triage : The Effect on Length of Stay.J Emerg Med (27-33)

Undang-Undang Republik Indonesia Rumah Sakit Nomor 44 Tahun 2009 